\title{
ADOPSI TEKNOLOGI BUDIDAYA IKAN PATIN PADA MASYARAKAT TANI DI DESA MARIANA - SUMATERA SELATAN
}

\author{
Zahri Nasution*), Emmy Dharyati ${ }^{*}$ dan Rupawan ${ }^{*}$
}

\begin{abstract}
ABSTRAK
Suatu penelitian yang bertujuan untuk mengetahui tingkat adopsi teknologi budidaya ikan patin pada masyarakat tani di Desa Mariana telah dilakukan dengan cara mensurvai seluruh (12 orang) petani ikan patin yang ada. Tujuan penelitian ini adalah untuk mengetahui kemampuan masyarakat tani di Desa Mariana dalam menyerap teknologi budidaya ikan patin. Pengumpulan data dilakukan pada bulan Juli 1994 dengan bantuan daftar pertanyaan yang terpola. Data pokok berkisar materi teknik budidaya ikan dan pengetahuan umum petani yang selanjutnya dianalisis secara deskriptif dan statistik.

Hasil penelitian menunjukkan bahwa adopsi masyarakat tani di Desa Mariana terhadap teknologi budidaya ikan patin cukup memadai, yaitu berkisar pada nilai sedang (53\%) hingga tinggi (75\%). Adopsi teknologi pada tahap persiapan kolam berkisar antara $47 \%$ hingga $100 \%$ dengan nilai rata-rata $67 \%$. Untuk tahap pengapuran dan pemupukan berkisar antara $52-76 \%$ dengan rata-rata $61 \%$, sedangkan tahap penebaran ikan, pemberian pakan dan panen berkisar antara $53 \%$ hingga $88 \%$ atau rata-rata $67 \%$. Pengetahuan umum petani telah memadai untuk menunjang usaha budidaya ikan yang mereka laksanakan dengan nilai $83 \%$ hingga $100 \%$ atau rata-rata $89 \%$.
\end{abstract}

\section{ABSTRACT: The adoption of Pangasius sutchi culture technology by farmers at Mariana village, South Sumatera province. By Zahri Nasution, Emmy Dharyati and Rupawan.}

An investigation on the adoption of Pangasius sutchi culture technology by the farmers at Mariana village was carried out by survey methods. The aim of this research was to evaluate the capability of farmers to adopt the technique of Pangasius sp. culture. The data was collected on July 1994 with appropriate questionaires.

The result showed that the technology of Pangasius sutchi culture were adopted by farmers to the extent of medium and high level category (53\% to $75 \%)$. The techniques of pond preparation for fish culture were adopted at $47-100 \%$ with $67 \%$ average from the defined standard. Level of adoption of liming and fertilization techniques were $52 \%-76 \%$ with $61 \%$ average, while fish stocking, feeding and fish harvesting were 53\%-88\% with $89 \%$ average.

The general knowledge of farmers on the technological aspect of Pangasius sutchi culture was favorable enough to support the application of the technology $(83 \%-100 \%)$ with the average of $89 \%$.

KEYWORDS: Pangasius culture; technology transfer, adoption.

\section{PENDAHULUAN}

Petani di Desa Mariana umumnya menanam padi sekali setahun. Sawah yang mereka gunakan ada yang berupa lahan kering (ladang) dan ada yang tergolong sawah lebak. Pemanfaatan hari-hari kerja lainnya biasanya mereka gunakan untuk bertanam palawija dan atau bekerja se- bagai buruh di pabrik. Namun akhir-akhir ini pemanfaatan hari kerja tersebut juga dilakukan dengan cara memelihara ikan.

Perkembangan budidaya ikan di Desa Mariana pertama kali ditandai oleh adanya petani yang mencoba untuk memelihara ikan gurame secara ekstensif. Pemeliharaan ikan gurame ini menggunakan pakan sederhana

\footnotetext{
*) Peneliti pada Loka Penelitian Perikanan Air Tawar Palembang
} 
berupa sisa dapur dan sisa sayuran. Kegiatan pemeliharaan ikan ini masih berlangsung hingga saat ini bahkan ada yang hanya bersifat memenuhi kebutuhan sendiri dan ada pula sebagai suatu usaha yang komersial.

Petani lainnya ada yang mencoba untuk memelihara ikan tambakan dalam kolam. Namun usaha ini juga tidak bersifat komersial. Hal ini disebabkan karena terbatasnya pengetahuan masyarakat pada masalah budidaya ikan. Di samping itu, untuk pemenuhan kebutuhan ikan konsumsi di Desa Mariana masih banyak terdapat sumbernya antara lain hasil tangkapan nelayan di Sungai Musi sekitar Desa Mariana dan di pasar Plaju (Kotamadya Palembang) yang jaraknya hanya sekitar $7 \mathrm{~km}$. Aspek lain yang kurang mendukung adalah keadaan tanah Desa Mariana yang sebagian besar adalah rawa yang relatif bersifat masam. Kesesuaian teknologi dalam hal ini menunjukkan pada sejauh mana teknologi dinilai sesuai dengan nilai-nilai sosial yang ada dan sesuai dengan kebutuhan pengguna (Ismail et al., 1994).

Namun demikian pada tahun 1991, Balai Penyuluhan Pertanian (BPP) yang berada di Desa Mariana mencoba mengaplikasikan hasil-hasil penelitian Loka Penelitian Perikanan Air Tawar Palembang dalam budidaya ikan patin di kolam. Hal ini berprinsip pada pendapat bahwa jenis. jenis ikan yang dianjurkan untuk dikembangkan adalah jenis ikan yang sudah tersedia benihnya (Wardoyo et al., 1993).

Khusus untuk pemeliharaan ikan patin, jenis yang dipelihara adalah Pangasius sutchi. Sistem pemeliharaan ikan ini cukup menguntungkan, yaitu sebesar $R p 2.680 .000$,- per tahun atau sekitar Rp 223.300 per bulan, namun membutuhkan investasi yang cukup tinggi, yaitu Rp3.470.000,- (Rupawan dan Nasution, 1995). Selang waktu 1 tahun, usaha pemeliharaan ikan patin ini mulai berkembang di masyarakat. Namun demikian keuntungan tersebut juga akan tergantung kepada pengaturan mekanisme pasar (Saleh, 1981). Laporan ini mengemukakan tingkat adopsi teknologi budidaya ikan patin di kalangan petani di Desa Mariana.

\section{METODOLOGI PENELITIAN}

Penelitian dilakukan dengan melakukan survai ke seluruh petani yang mengusahakan budidaya ikan patin di Desa Mariana. Pada tahap awal penelitian dicatat seluruh petani yang memelihara ikan patin di Desa Mariana, yaitu berjumlah 12 orang. Dalam penelitian ini seluruh petani dijadikan contoh. Pengumpulan data dilakukan pada bulan Juli 1994 dengan bantuan daftar pertanyaan yang telah disiapkan. Data pokok berkisar pada aspek teknik budidaya ikan patin dan pengetahuan umum petani.

Tingkat adopsi petani terhadap teknologi budidaya ikan patin diukur dengan cara membuat penilaian terhadap pelaksanaan teknik budidaya yang dilaksanakan oleh petani.

Dasar pengukuran yang dipakai adalah pengukuran kualitatif. Data kualitatif ini dituangkan dalam bentuk angka skor/nilai (Lampiran 1 dan 2). Ukuran kualitatif ini merupakan modifikasi model pengukuran yang dilakukan dalam meng. evaluasi pengaruh petak percobaan budidaya ikan yang dilakukan oleh Nasution (1991) pada masyarakat tani di Karang Agung Ulu, Sumatera Selatan. Dalam analisis, adopsi teknologi budidaya ikan pada petani dibedakan atas adopsi tinggi, sedang dan rendah. Petani dengan adopsi tinggi ditunjukkan dengan menerapkan $71-100 \%$ teknik budidaya ikan patin yang menjadi standar penilaian. Adopsi sedang dengan menerapkan 53-70\%, sedangkan adopsi rendah penerapannya kurang dari $52 \%$.

Teknik budidaya ikan dikelompokkan menjadi 3 tahap, yaitu:

1. Tahap persiapan kolam (No. $1 \mathrm{~s} / \mathrm{d} 6$ ).

2. Tahap pengapuran dan pemupukan (No. $7 \mathrm{~s} / \mathrm{d}$ 13 ).

3. Tahap penebaran ikan, pemberian pakan dan panen (No.14 s/d 18).

Di samping tahap teknik budidaya ikan tersebut ditambah pula dengan kategori pengetahuan umum petani, semua diuji keeratan hubungannya dengan tingkat adopsi teknik budidaya ikan pada masing-masing petani. Pengujian keeratan hubungan dilakukan menggunakan koefisien korelasi Rank Spearman dengan pasangan pengujian sebagai berikut;
a. X1 dengan $Y$
b. X2 dengan $Y$
c. X3 dengan $Y$
d. X4 dengan $Y$, 
di mana:

X1 adalah variabel persiapan kolam

$\mathrm{X} 2$ adalah variabel pengapuran dan pemupukan

X3 adalah variabel penebaran ikan pemberian pakan dan panen

X4 adalah variabel pengetahuan umum petani

$\mathrm{Y}$ adalah variabel adopsi teknik budidaya ikan secara menyeluruh.

Rumus koefisien korelasi Rank Spearman (Siegel, 1988) adalah sebagai berikut:

$$
r_{s}=1-\frac{6}{n\left(n^{2}-1\right)} \sum_{i=1}^{n}(h i-k i)^{2}
$$

di mana:

$\begin{array}{ll}\mathrm{n} & \text { adalah jumlah responden } \\ \mathrm{hi} & \text { adalah pangkat untuk Xi } \\ \mathrm{ki} & \text { adalah pangkat untuk } \mathrm{Yi}\end{array}$

Hipotesa yang diuji adalah: $\mathrm{H}_{\mathrm{O}}=0$

$\mathrm{Ho}>0$

Hipotesa nol berarti pernyataan tidak ada hubungan yang erat antara variabel $\mathrm{X}$ dan $\mathrm{Y}$ yang diuji, dengan ketentuan jika $r_{s}$ hitung $>r_{s}$ tabel maka hipotesa nol ditolak.

\section{HASIL DAN PEMBAHASAN}

\section{Adopsi Teknologi Budidaya Ikan}

Tingkat adopsi teknologi budidaya ikan patin di kalangan petani di Desa Mariana secara menyeluruh (tahap persiapan kolam, pengapuran dan pemupukan, penebaran ikan, pemberian pakan dan panen) berkisar antara $53-75 \%$ dari teknologi yang dianggap standar dalam evaluasi ini. Nilai adopsi tersebut berkisar sedang (8 orang dengan nilai $53 \%$ hingga $67 \%$ ) hingga tinggi (4 orang dengan nilai $71 \%$ hingga $75 \%$ ) (Tabel 1). Perbedaan persentase adopsi teknologi ini dapat dipengaruhi oleh berbagai faktor antara lain kesesuaian dengan kebutuhan pengguna (Ismail et al., 1994), aspek sosial masyarakat (Soetrisno, 1991), tingkat keterampilan petani, ketersediaan tenaga kerja dan modal petani untuk dapat menerapkan teknologi tersebut.

Secara terinci Tabel 1 menggambarkan bahwa seluruh variabel teknologi diadopsi oleh petani pada tingkat yang lebih besar dari $50 \%$, kecuali untuk satu orang petani dan inipun terbatas pada tahap persiapan kolam yang nilainya hanya men- capai $47,06 \%$. Hal ini menunjukkan bahwa ratarata petani di Desa Mariana telah melaksanakan budidaya seperti yang ditetapkan meskipun masih terdapat beberapa kekurangan baik dalam persiapan kolam, pengapuran, pemupukan dan variabel lainnya. Selanjutnya akan diuraikan variabel apa dan bagaimana hubungannya terhadap adopsi teknologi budidaya ikan patin di kalangan petani di Desa Mariana.

\section{Tahap Persiapan Kolam}

Salah satu cara untuk mempersiapkan kolam di lahan masam antara lain dapat dilakukan melalui teknik pengeringan dasar kolam yang sempurna, pengapuran tanah dan pemupukan dengan pupuk anorganik (Husnah dan Gaffar, 1992). Selanjutnya kolam dapat dipupuk dengan $\mathrm{N}, \mathrm{P}$ dan $\mathrm{K}$ atau pupuk kandang guna menambah kesuburan kolam. Proses pemupukan dilaksanakan setelah $\mathrm{pH}$ air kolam stabil setelah perlakuan pengapuran.

Tingkat adopsi petani dalam mempersiapkan kolam untuk budidaya ikan dalam kolam di Desa Mariana berkisar antara $47-100 \%$ dari persyaratan teknik budidaya ikan yang ditetapkan. Hal ini memberikan arti bahwa ada petani yang hanya sedikit menerapkan teknologi persiapan kolam. Namun demikian rata-rata keseluruhan petani mencapai tingkat adopsi $67 \%$. Hal ini berarti bahwa sebagian besar petani telah mengetahui dan menerapkan cara-cara mempersiapkan kolam. Hasil pengujian secara statistik menunjukkan bahwa variabel teknologi persiapan kolam berhubungan erat dengan tingkat adopsi dicapai petani dalam budidaya ikan.

Meskipun demikian belum seluruhnya teknik mempersiapkan kolam dilakukan oleh petani. $\mathrm{Hal}$ ini terlihat dari hasil survai diketahui bahwa dalam mempersiapkan kolam petani, umumnya petani hanya membersihkan rumputnya, sedangkan untuk pemberantasan ikan liar petani menggunakan jaring penggiring saja, tidak menggunakan obat- obatan, bahkan ada petani yang tidak memberantasnya sama sekali.

\section{Tahap Pengapuran dan Pemupukan}

Pengapuran dan pemupukan dilakukan setelah proses reklamasi selesai. Pengapuran dapat dilakukan dengan cara mengapur air dengan dosis yang didasarkan atas nilai keasaman total- 
Tabel 1. Jumlah nilai (skor) setiap variabel adopsi teknologi budidaya ikan patin pada masyarakat tani di Desa Mariana 1994.

Table 1. Total score of each variable on the adoption of technology of Pangasius sutchi cultured by fish farmers in Mariana village, 1994.

\begin{tabular}{|c|c|c|c|c|c|c|c|c|c|}
\hline \multirow{3}{*}{$\begin{array}{c}\begin{array}{c}\text { No. Urut } \\
\text { petani } \\
\text { Farmer no. }\end{array} \\
1 .\end{array}$} & \multicolumn{9}{|c|}{$\begin{array}{l}\text { Jumlah skor teknologi yang dievaluasi } \\
\text { (Total score of technology evaluated) }\end{array}$} \\
\hline & \multicolumn{2}{|c|}{ I } & \multicolumn{2}{|c|}{ II } & \multicolumn{2}{|c|}{ III } & \multirow{2}{*}{$\begin{array}{c}\begin{array}{c}\text { Total } \\
\text { (I+II+III) }\end{array} \\
39(71)\end{array}$} & \multicolumn{2}{|r|}{ IV } \\
\hline & 13 & (76.47) & 16 & (76.19) & 10 & $(58.82)$ & & 24 & (100.00) \\
\hline 2. & 11 & $(64.71)$ & 11 & $(52.38)$ & 9 & (52.94) & $31(56)$ & 20 & $(83,33)$ \\
\hline 3. & 14 & (82.35) & 14 & (66.67) & 12 & (70.59) & $40(73)$ & 22 & (91.67) \\
\hline 4. & 17 & (100.00) & 13 & $(61.90)$ & 11 & $(64.71)$ & $41(75)$ & 21 & $(87.50)$ \\
\hline 5. & 8 & (47.06) & 11 & (52.38) & 15 & (88.24) & $34(62)$ & 20 & (83.33) \\
\hline 6. & 11 & (64.71) & 12 & $(57.14)$ & 9 & (52.91) & $32(58)$ & 21 & (87.50) \\
\hline 7. & 9 & (52.94) & 11 & (52.38) & 14 & (82.35) & $34(62)$ & 20 & (83.33) \\
\hline 8. & 12 & (70.89) & 13 & $(61.90)$ & 12 & (70.59) & $37(67)$ & 21 & (87.50) \\
\hline 9. & 8 & $(47.06)$ & 12 & $(57.14)$ & 9 & (52.91) & $29(53)$ & 20 & (83.33) \\
\hline 10. & 12 & (70.89) & 14 & $(66.67)$ & 12 & (70.59) & $36(65)$ & 21 & (87.50) \\
\hline 11. & 11 & (64.71) & 23 & (61.90) & 11 & $(64.71)$ & $35(64)$ & 21 & (87.50) \\
\hline 12. & 14 & (82.35) & 13 & $(61.90)$ & 12 & (70.59) & $39(71)$ & 22 & (91.70) \\
\hline
\end{tabular}

I. Tahap persiapan kolam (pond preparation).

II. Tahap pengapuran dan pemupukan (liming and fertilization).

III. Tahap penebaran ikan, pemberian pakan dan panen (fish stocking, feeding and harvesting).

IV. Pengetahuan umum petani (general knowledge of farmer).

(...) Persentase terhadap nilai maksimum (percentage to maximum value).

nya. Namun demikian berdasarkan hasil penelitian diketahui bahwa pengaruh pemberian kapur terhadap keasaman air akan lebih lama jika kapur diaplikasikan di tanah dasar dan pematang kolam (Gaffar dan Husnah, 1991).

Pada penelitian ini diketahui bahwa tingkat adopsi petani terhadap teknologi pengapuran dan pemupukan kolam untuk budidaya ikan patin di Desa Mariana berkisar antara $52-76 \%$, dengan rata-rata $61 \%$. Angka ini memberikan gambaran bahwa rata-rata lebih dari $50 \%$ teknik pengapuran dan pemupukan telah diketahui petani. Hal ini merupakan hal pokok yang bertujuan memperbaiki kualitas air kolam dan meningkatkan kesuburan kolam yang keadaan asalnya relatif masam.

Hasil pengujian secara statistik menunjukkan bahwa teknologi pengapuran dan pemupukan kolam tidak berhubungan erat dengan tingkat adopsi teknologi budidaya ikan yang dicapai petani. Hasil tersebut menunjukkan bahwa pengertian petani terhadap manfaat pengapuran dan pemupukan terhadap peningkatan kualitas air kolam telah memadai. Pengujian secara statistik ini didukung dengan hasil survai di lapangan yang memperlihatkan bahwa petani melakukan pengapuran dengan dosis $6 \mathrm{~kg} / \mathrm{m}^{2}$ atau lebih. 
Di lain pihak bahkan ada petani yang melakukan pemupukan $\mathrm{P}$ dan $\mathrm{N}$ serta pupuk kandang. Namun dari keseluruhan petani tidak ada yang membuat pintu air kolam. Air kolam tergantung kepada keadaan air tanah dan mendapatkan tambahan pada saat hujan, sedangkan pada musim kemarau ditambah dengan pompa air dari sumur bor. Hal ini akan bermanfaat untuk setidak-tidaknya meningkatkan volume air yang pada musim kemarau hanya berkisar $40-50 \mathrm{~cm}$ dari dasar kolam.

\section{Tahap Penebaran Ikan, Pemberian Pakan dan Panen}

Penebaran ikan per satuan luas kolam akan mempengaruhi pertumbuhan ikan yang dipelihara karena semakin tinggi padat penebaran mengakibatkan metabolisme meningkat yang mengakibatkan nilai oksigen rendah (Shang dalam Lannan et al., 1983). Di samping itu, padat penebaran rendah cenderung memberikan konversi pakan yang lebih baik daripada kepadatan tinggi (Sumastri dan Rusmaedi, 1991).

Pada penelitian ini diketahui bahwa dalam hal penebaran ikan per satuan luas kolam, sebagian petani belum mengetahui berapa kepadatan yang dianggap optimum. Adopsi petani dalam kategori penebaran ikan dan pemberian pakan dan panen secara keseluruhan berkisar antara $53 \%$ hingga $88 \%$ atau rata-rata $67 \%$.

Hasil pengujian secara statistik menunjukkan bahwa teknologi dalam kategori penebaran ikan, pakan dan panen tidak berhubungan erat dengan tingkat adopsi teknologi budidaya ikan yang dicapai petani. Berarti pengertian petani terhadap padat penebaran ikan, penggunaan pakan dan cara panen telah cukup.

Di samping itu, belum optimalnya tingkat adopsi petani terhadap variabel penebaran ikan dan pemberian pakan ini disebabkan oleh beberapa hal antara lain kurangnya permodalan mereka untuk membeli benih ikan dan pakannya. Harga pakan yang cukup tinggi membuat mereka merubahnya dengan cara memafaatkan tanaman air, limbah teri dan dedak yang dibuat seperti pakan pelet.

Sesuai dengan pendapat Mosher (1985) bahwa agar pembangunan pertanian (dalam arti luas termasuk perikanan) dapat berhasil, harus dipenuhi syarat-syarat pokok dan pelancar.
Dengan melihat syarat-syarat yang dikemukakan oleh Mosher maka jika dihubungkan dengan keadaan lokasi petani di Desa Mariana khususnya untuk menunjang budidaya ikan belumlah memadai. Hal ini antara lain terlihat dari belum tersedianya benih ikan secara lokal di tingkat petani (benih berasal dari Sukabumi), begitu pula pakannya yang tersedia hanya makanan ikan berupa dedak. Dedak inipun didapatkan hanya pada saat panen padi, sedangkan tepung limbah teri harus dibeli dari pasar yang jaraknya cukup jauh dari lokasi pemeliharaan.

\section{Pengetahuan Umum Petani}

Pengetahuan umum petani dapat dikatakan memadai untuk menunjang usaha budidaya ikan yang mereka laksanakan. Hal ini terlihat dari adopsi mereka terhadap variabel yang dikategorikan sebagai pengetahuan umum yang mencapai $83-100 \%$ atau rata-rata $88 \%$. Di samping itu, terlihat dari hasil pengujian secara statistik bahwa tingkat pengetahuan umum petani tidak berhubungan erat dengan tingkat adopsi teknologi petani. Hal ini berarti tingkat pengetahuan umum petani telah cukup memadai, meskipun di antara mereka ada yang belum mengetahui tentang beberapa hal, misalnya:

a. Belum pernah keluar daerah dan mendapat layanan pembinaan tentang budidaya ikan.

b. Belum mengetahui tentang pestisida dan belum mengerti tentang kegunaannya.

c. Belum mengetahui tentang bibit unggul dan tentang kegunaannya.

d. Belum mengetahui betul tentang cara pengolahan tanah dan persiapan kolam di daerah seperti yang mereka lakukan saat ini.

e. Belum berpengalaman mengikuti organisasi misalnya Kelompok Tani dan KUD.

f. Belum pernah mengikuti kursus tani atau kursus lainnya tentang perikanan.

\section{KESIMPULAN DAN SARAN}

Berdasarkan hasil penelitian ini diketahui bahwa tingkat adopsi petani di Desa Mariana, Sumaera Selatan terhadap tekonologi budidaya ikan patin secara keseluruhan cukup memadai dengan nilai sedang (53\%) hingga tinggi (75\%). Tingkat adopsi teknologi terhadap kategori yang 
ditetapkan adalah untuk tahap persiapan kolam berkisar antara $47-100 \%$ dengan nilai rata-rata $67 \%$. Unituk tahap pengapuran dan pemupukan berkisar antara $52-76 \%$ dengan rata-rata $61 \%$.

Di samping itu, pada tahap penebaran ikan, pemberian pakan dan panen berkisar antara 53 $88 \%$ atau rata-rata $67 \%$. Sedangkan pengetahuan umum petani dapat dikatakan memadai untuk menunjang usaha budidaya ikan yang mereka laksanakan. Hal ini terlihat dari adopsi mereka terhadap variabel yang dikategorikan sebagai pengetahuan umum yang mencapai $83-100 \%$ atau rata-rata $88 \%$.

Dalam rangka meningkatkan pengetahuan umum petani dalam menunjang budidaya ikan maka diperlukan beberapa macam kursus atau bahan ceramah (lembar informasi pertanian) yang berhubungan dengan budidaya ikan patin dalam kolam. Di samping itu, penyediaan benih ikan yang tepat waktu dan tersedia tidak jauh dari lokasi petani merupakan suatu hal yang penting untuk mengantipasi pengembangan budidaya ikan di masa mendatang.

\section{DAFTAR PUSTAKA}

Gaffar, A.K. dan Husnah. 1991. Pembesaran ikan nila (Oreochromis niloticus) di kolam rawa. Bull. Penel. Perik. Darat. 10(1). Balitkanwar, Bogor. Hal. 55-59.

Husnah dan A.K.Gaffar. 1992. Pendayagunaan lahan rawa untuk budidaya ikan. Bull. Penel. Perik. Darat, 11(2), Balitkanwar, Bogor, hal. 115-122.

Ismail, W.; B. Priono; H. Mubarak dan F. Cholik. 1994. Penelitian faktor-faktor yang berpengaruh terhadap tingkat adopsi teknologi Keramba Jaring Apung mini di beberapa waduk/danau di Pulau Jawa dan Sumatera. Bull. Penel. Perik, Puslitbang Perikanan, Jakarta, hal. 11-34.
Mosher, A.T. 1985. Menggerakkan dan membangun pertanian. Penerbit C.V. Yasaguna, Jakarta.

Nasution, Z. 1991. Evaluasi pengaruh petak percobaan budidaya ikan pada masyarakat tani di lahan pasang surut Karang Agung Ulu - Sumatera Selatan, Bull. Penel. Perik. Darat, 10 (2), Balitkanwar, Bogor, hal. 120-131.

Rupawan dan Z. Nasution. 1995. Analisis ekonomi uji adaptasi pembesaran ikan patin (Pangasius sutchi) dalam kolam. Prosiding PPEHP Perikanan Perairan Umum, Palembang, 27-28 Februari 1994, Sub Balitkanwar Palembang

Saleh, S. 1981. Kendala keterpaduan pasar ikan laut segar di Jawa Tengah, Bull. Penel. Perik, Puslitbang Perikanan, Jakarta, hal. 481-490.

Shang, Y.C. 1983, Stocking practices in pond fish culture. In Principles and practices of pond aquaculture, by Lannan, J.E., R. Oneal Smitherman and George Tchobanoglous. Oregon State University, 91-99 p.

Siegel, S. 1988. Statistik non-parametrik untuk ilmuilmu sosial. Penerbit P'T. Gramedia. Jakarta

Soetrisno, L. 1991. Aspek sosiologi dalam penelitian sosial ekonomi pertanian, Materi Latihan Metoda Penelitian Agro Ekonomi, Cisarua-Bogor, 14 Januari- 2 Maret 1991. Puslit Sosek Pertanian, Badan Litbang Pertanian, Bogor.

Sumastri, S. dan Rusmaedi. 1991. Pengaruh padat penebaran terhadap pertumbuhan dan kelangsungan hidup benih manfish (Pterophylum scalare) selama penampungan, Bull. Penel. Perik. Darat, 10 (1), Balitkanwar, Bogor, hal. 77-81.

Wardoyo, S.E.; E. Pratiwi dan M.F. Sukadi. 1993. Keseimbangan populasi ikan di Sungai Mahakam dan Sungai Kapuas sebagai perțimbangan dalam pengelolaan perikanan, Bull. Penel. Perik, Ed. Khusus PLHP. Puslitbang Perikanan, Jakarta, hal. 25-34. 
Lampiran 1. Penilaian variabel adopsi teknologi

Appendix 1. Scoring of variables of technology adoption.

No. Uraian variabel teknologi (Variables of technology)

Nilai (Score)

\section{Tahap Persiapan Kolam (Pond Preparation Stage)}

1. Persiapan pengolahan tanah (Pond soil treatment)

a. Diolah hingga berlumpur (Treatment to build up mud)

b. Hanya dibersihkan rumputnya (Just removing grass)

c. Tanpa diolah sama sekali (No treatment)

2. Pemberantasan ikan liar yang terdapat di dalam kolam (Erradication of wild fishes)

a. Menggunakan obat kimia (Chemical poisoning)

b. Menggunakan jaring penggiring (Seining)

c. Tidak diberantas sama sekali (No erradication)

3. Melakukan pengeringan kolam sebelum tanah dasar kolam diolah (Pond draining before soil treatment)

a. Dikeringkan hingga berlumpur (Complete draining to build up mud)

b. Hanya pengurangan air hingga sisa $30 \mathrm{~cm}$ (Draining and leaving $30 \mathrm{~cm}$ water depth)

c. Tidak dikeringkan sama sekali (No draining)

4. Penggenangan kolam setelah pengeringan kolam (Flooding after draining)

a. Digenangi selama beberapa hari (Flooding for several days)

b. Hanya ditambah air saja ketika hujan turun (Flooding by rainfall only)

c. Tidak digenangi sama sekali (No flooding)

5. Pembilasan kolam setelah air genangan dibuang dan air dibuang kembali (Flushing and redraining the pond)

a. Ya, dilakukan (Flushing and redraining)

b. Ya, tetapi tidak dikeringkan kembali (Flushing without draining)

c. Tidak ada pembilasan sama sekali (No flushing)

6. Melaksanakan pengapuran terhadap kolam (Liming)
a. Ya (Liming)
b. Tidak (No liming)

\section{Tahap Pengapuran dan Pemupukan (Liming and Fertilizing} Stages):

7. Dosis kapur yang dilakukan (Liming dosage)
a. $60 \mathrm{~g}$ per $\mathrm{m}^{2}$
b. $30 \mathrm{~g}$ per $\mathrm{m}^{2}$
c. Kurang dari $30 \mathrm{~g}$ per $\mathrm{m}^{2}$ (Less than $30 \mathrm{~g} / \mathrm{m}^{2}$ )

8. Cara pengapuran kolam (Methods of liming)

a. Disebar merata didasar kolam (Broadcasting on the pond bottom) 3

b. Ditempat terpisah pada dasar kolam (Piling on the different parts of the 2 pond bottom)

c. Hanya ditempatkan di pematang kolam (Piling on the banks of the pond) 
Lampiran 1 lanjutan

(Appendix 1 continued)

9. Pemupukan kolam (Fertilizing the pond)

a. Ya, pupuk $\mathrm{N}$ dan $\mathrm{P}$ ( $N$ and $P$ fertilizers)

b. Ya, pupuk P saja atau N saja atau pupuk kandang (Either $N, P$ or manure)

c. Tanpa dipupuk sama sekali (No fertilizing)

10. Dosis pupuk $\mathrm{N}$ (Dosage of $\mathrm{N}$ fertilizer)
a. $335 \mathrm{~g}$ per $\mathrm{m}^{2}\left(335 \mathrm{~g} / \mathrm{m}^{2}\right)$
b. $167,5 \mathrm{~g}$ per $\mathrm{m} 2\left(167.5 \mathrm{~g} / \mathrm{m}^{2}\right)$
c. Kurang dari $167,5 \mathrm{~g}$ per $\mathrm{m}^{2}$ (Less than $167.5 \mathrm{~g} / \mathrm{m}^{2}$ )

11. Dosis pupuk $\mathrm{P}$ (Dosage of $P$ fertilizer)

a. $20 \mathrm{~g}$ per meter persegi $\left(20 \mathrm{~g} / \mathrm{m}^{2}\right)$

b. $10 \mathrm{~g}$ per meter persegi $\left(10 \mathrm{~g} / \mathrm{m}^{2}\right)$

c. Kurang dari $10 \mathrm{~g}$ per meter persegi (Less than $10 \mathrm{~g} / \mathrm{m}^{2}$ )

12. Pemasukan air ketika hujan (Filling during raining)

a. Ya, setiap ada hujan (Whenever raining) 3

b. Ya, seminggu sekali menggunakan sumber air lain (Once a week using 2 other water source)

c. Tidak pernah sama sekali (No filling)

13. Bentuk konstruksi pintu air (Type of water gate)

a. Permanen (papan atau paralon) (Permanent wooden plank or PVC pipe) 3

b. Tanah dan perangkap ikan (Soil and fish trap)

c. Tanah saja (Soil without trap)

III. Tahap Penebaran Ikan, Pemberian Pakan dan Panen (Stocking, Feeding and Harvesting Stages):

14. Padat tebar ikan dalam kolam (Stocking density)
a. 10 ekor/meter persegi $\left(10 \mathrm{fish} / \mathrm{m}^{2}\right)$
b. 5 ekor per meter persegi ( $5 \mathrm{fish} / \mathrm{m}^{2}$ )
c. Kurang dari 5 ekor per meter persegi (Less than $5 \mathrm{fish} / \mathrm{m}^{2}$ )

15. Pakan Ikan (Feeding)

a. Diberi pakan tambahan (With additional feeds)

b. Tidak diberi pakan tambahan (Without additional feeds)

16. Jenis pakan tambahan (Type of additional feeds)
a. Pakan pelet komersial (Commercial pelleted feed)
b. Pakan lain dibuat sendiri (Self prepared pelleted feed)
c. Sisa dapur dan dedak saja (Rice brand and kitchen waste)

17. Kuantitas pemberian pakan per hari (Daily feeding)

a. Lebih dari $20 \%$ dari bobot populasi ikan (More than $20 \%$ of total weight) 3

b. $5 \%$ dari bobot populasi ikan ( $5 \%$ of total weight)

c. Kurang dari $5 \%$ dari populasi ikan (Less than $5 \%$ of total weight) 
Lampiran 1 lanjutan

(Appendix 1 continued)

\section{No.}

Uraian variabel teknologi (Variables of technology)

Nilai (Score)

18. Pemeliharaan rumput di pematang kolam (Controlling the grass on the pond dike)

a. Ditebas tetapi masih menutup tanah pematang (Partial cutting) 3

b. Tidak ditebas sama sekali (rumput dibiarkan saja) (No cutting)

c. Ditebas hingga tidak terdapat rumput di pematang (Complete cutting)

19. Cara melaksanakan panen ikan (Harvest method)

a. Menggiringnya dengan jaring dan mengurangi air kolam (Seining and partial draining)

b. Menggiringnya dengan jaring saja (Seining)

c. Kolam dikeringkan sama sekali (Complete draining) 
Lampiran 2. Penilaian pengetahuan umum petani.

Appendix 2. Scoring on general knowledge of farmers.

No.

1. Pernah keluar daerah dan mendapat layanan pembinaan tentang budidaya ikan (Getting information from other places or extension service)
a. Pernah (Yes)
b. Tidak pernah (Never)

2. Pernah berkonsultasi dengan petugas perikanan yang ada di sekitar lokasi pemeliharaan ikan (Getting advices from local fishery agencies)
a. Pernah (Yes)
b. Tidak pernah (Never)
3. Pernah menonton film tentang budidaya ikan misalnya nonton televisi atau penerangan lainnya (Getting knowledge from audiovisual or other information media)
a. Pernah (Yes)

b. Tidak pernah (Never)

4. Pernah mengikuti ceramah dari petugas perikanan (Getting information from fishery extension service)
a. Pernah (Yes)
b. Tidak pernah (Never)

5. Pernah mendengarkan siaran pedesaan (Getting information from rural radio programs)
a. Pernah (Yes)
b. Tidak pernah (Never)

6. Mengetahui tentang pestisida dan mengerti tentang kegunaannya (Have knowledge on perticides and its application)
a. Mengetahui (Yes)
b. Tidak mengetahui (No)

7. Mengetahui tentang pupuk dan kegunaannya (Have knowledge on fertilizer and its application)
a. Mengetahui (Yes)
b. Tidak mengetahui (No)

8. Mengetahui tentang bibit unggul dan tentang kegunaannya (Have knowledge on qualities of superior seeds and their use)
a. Pernah (Yes)
b. Tidak pernah (Never)

9. Pernah membaca brosur tentang budidaya ikan (Getting information from aquaculture brocures)
a. Pernah (Yes)
b. Tidak pernah (Never) 
Lampiran 2 lanjutan

(Appendix 2 continued)

No.

Uraian (Item)

Nilai (Score)

10. Mengetahui cara pengolahan tanah dan persiapan kolam di daerah seperti tempat bapak sekarang ini (Have knowledge on local soil treatment and pond preparation)

a. Mengetahui (Yes)

b. Tidak mengetahui (Never)

11. Berpengalaman mengikuti organisasi misalnya Kelompok Tani dan KUD

(Have experience in community organization such as farmers group, cooperative or KUD)

a. Berpengalaman (Yes)

b. Tidak berpengalaman (No experience)

12. Pernah mengikuti kursus tani atau kursus lainnya tentang perikanan

(Joining fish farming training course)

a. Pernah (Yes)

b. Tidak pernah (Never) 